\title{
Corticotrophin-releasing factor, related peptides, and receptors in the normal and inflamed gastrointestinal tract
}

\author{
Roeland Buckinx ${ }^{1}$, Dirk Adriaensen ${ }^{1}$, Luc Van Nassauw ${ }^{1,2}$ and Jean-Pierre Timmermans ${ }^{1 *}$ \\ Laboratory of Cell Biology and Histology, University of Antwerp, Antwerp, Belgium \\ 2 Laboratory of Human Anatomy and Embryology, University of Antwerp, Antwerp, Belgium
}

Edited by:

Yvette France Taché, University of California Los Angeles, USA

\section{Reviewed by:}

Aditi Bhargava, University of California

San Francisco, USA

Ekaterini Chatzaki, Democritus

University of Thrace, Greece

Charalabos Pothoulakis, University of

California at Los Angeles, USA

*Correspondence:

Jean-Pierre Timmermans, Laboratory

of Cell Biology and Histology,

Department of Veterinary Sciences,

University of Antwerp,

Groenenborgercampus,

Groenenborgerlaan 171, B-2020

Antwerpen, Belgium.

e-mail: jean-pierre.timmermans@ua.

ac.be
Corticotrophin-releasing factor (CRF) is mainly known for its role in the stress response in the hypothalamic-pituitary-adrenal axis. However, increasing evidence has revealed that CRF receptor signaling has additional peripheral effects. For instance, activation of CRF receptors in the gastrointestinal tract influences intestinal permeability and motility. These receptors, CRF1 and CRF2, do not only bind CRF, but are also activated by urocortins. Most interestingly, CRF-related signaling also assumes an important role in inflammatory bowel diseases in that it influences inflammatory processes, such as cytokine secretion and immune cell activation. These effects are characterized by an often contrasting function of CRF1 and CRF2. We will review the current data on the expression of CRF and related peptides in the different regions of the gastrointestinal tract, both in normal and inflamed conditions. We next discuss the possible functional roles of CRF signaling in inflammation. The available data clearly indicate that CRF signaling significantly influences inflammatory processes although there are important species and inflammation model differences. Although further research is necessary to elucidate this apparently delicately balanced system, it can be concluded that CRF-related peptides and receptors are (certainly) important candidates in the modulation of gastrointestinal inflammation.

Keywords: corticotrophin-releasing factor, urocortin, inflammation, gastrointestinal tract

\section{INTRODUCTION}

Corticotrophin-releasing factor (CRF), also called corticotrophinreleasing hormone (CRH; Hauger et al., 2003; Gallagher et al., 2008), was first described in the ovine hypothalamus (Vale et al., 1981) and is mainly known for its role in the hypothalamus-pituitary-adrenal (HPA) axis. Stressors of intrinsic or extrinsic origin induce the secretion of CRF from the hypothalamus, which in turn evokes the release of adrenocorticotropic hormone (ACTH) from the pituitary gland. ACTH finally stimulates glucocorticoid secretion by the adrenal cortex (Mawdsley and Rampton, 2005; Kyrou and Tsigos, 2009). Stress is known to aggravate gastrointestinal (GI) disorders, such as Crohn's disease (CD), ulcerative colitis (UC), and irritable bowel syndrome (IBS; Mawdsley and Rampton, 2005; Hisamatsu et al., 2007). CD and UC have a clear inflammatory component and hence are classified as inflammatory bowel diseases (IBD). The cause of symptoms of IBS patients, however, is not clear. Several epidemiological studies have dealt with the influence of (psychological) stress on GI disorders, but interpretation is difficult due to considerable variation in study design and quality (Mawdsley and Rampton, 2005; Hisamatsu et al., 2007; Musial et al., 2008; Camara et al., 2009; Zijdenbos et al., 2009). However, several in vitro and in vivo studies indicate a clear influence of CRF and related peptides on GI functions and inflammation. This subject has also been touched on in other interesting reviews, which discussed the role of CRF in the different aspects of intestinal function (Larauche et al., 2009) or the influence on different components of the immune response (Kiank et al., 2010). It is becoming increasingly clear that neuro-immune interaction can substantially influence the immune response in the GI tract (Gross and Pothoulakis, 2007). An important prerequisite to understanding the mechanisms of this interaction is a thorough knowledge of the neuronal and immune cell types involved as well as a profound insight into the expression of different players of the CRF signaling system in these cells. This review will focus on the current data regarding the expression of these CRF-related peptides, e.g., CRF, urocortins (UCNs), and CRF receptors, in the GI tract and discuss the influence of inflammation on their expression profile, with special attention to the different inflammation models used.

\section{CRF, UROCORTINS, AND THEIR RECEPTORS}

Although a CRH had already been discovered in 1955 (Saffran and Schally, 1955), it was not until 1981 that Vale et al. (1981) succeeded in isolating CRF, consisting of 41 amino acids, from the ovine hypothalamus. Later studies revealed the presence of highly homologous proteins in both mammalian and non-mammalian species (Rivier et al., 1983; Thompson et al., 1987; Seasholtz et al., 1991; Lovejoy and Balment, 1999; Okada et al., 2005). Phylogenic analyses have shown that the CRF-like peptides constitute an ancient lineage, with origin in the Precambrian period as a peptide involved in osmoregulation (Lovejoy and Jahan, 2006; Lovejoy, 2009). CRF, just like many hormones, is derived from a precursor protein, designated as prepro-CRF and consisting of 196 amino acids (Furutani et al., 1983; Shibahara et al., 1983). The amount of free CRF can be controlled by a CRF-binding protein (Behan et al., 1995).

Corticotrophin-releasing factor acts through activation of two receptors: CRF1 and CRF2. A third CRF receptor seems to be restricted to the catfish species (Arai et al., 2001). CRF receptors are G-protein-coupled receptors (GPCRs) of the secretin receptor 
family, also called class B. They belong to subfamily B2, as do other hormone and neuropeptide receptors (Hauger et al., 2003). CRF receptors have been reported to couple to several G-proteins, the contribution of which depends on cellular and genetic background (Blank et al., 2003; Dautzenberg et al., 2004a; Gutknecht et al., 2009). The main signaling pathway is cAMP-dependent, thus initiated by $\mathrm{G}_{\mathrm{s}}$ proteins and subsequent adenylyl cyclase activation. Effects of $\mathrm{G}_{\mathrm{q}}$ protein activation, linked to the phospholipase $\mathrm{C}$ pathway, and to a lesser extent $\mathrm{G}_{\mathrm{i} / \mathrm{o}}$ activation, however, have also been observed in relation to CRF receptor stimulation (Hillhouse and Grammatopoulos, 2006; Gutknecht et al., 2009). Interpretation of the results is further complicated by the cross-talk between different G-protein-coupled signaling cascades, converging on the MAP/ ERK pathway, and by interaction between CRF receptors and other GPCRs (Brar et al., 2004; Hillhouse and Grammatopoulos, 2006; Gutknecht et al., 2009, 2010; Van Kolen et al., 2010). Several splice variants of CRF receptors have been identified. In the case of CRF1, only the main CRF1(a) isoform was thought to be a functional CRF receptor. However, a recent paper by Wu et al. (2011) identified a functional isoform, CRF1(i), in the BON-N1 cell line, and confirmed its expression in human tissue, including the ileum. The other variants display low ligand affinity or are unable to induce intracellular signaling (Dautzenberg et al., 2001; Pisarchik and Slominski, 2004; Karteris et al., 2010). These isoforms might have a regulatory influence on CRF1 signaling but although interesting, this role remains rather speculative and requires further research (Pisarchik and Slominski, 2004; Zmijewski and Slominski, 2010). CRF2, on the other hand, exists in three functional splice variants (Lovenberg et al., 1995b; Kostich et al., 1998; Hauger et al., 2003). Both CRF2(a) and CRF2(b) have been found in mammalian tissues, while only CRF2(a) has been described in non-mammalian species and CRF2(c) has been detected solely in human tissue (Hauger et al., 2003). Studies on mouse and tree shrew CRF2 show higher ligand selectivity of CRF2(b) compared to CRF2(a), while the ligand selectivity of human CRF2(a) and CRF2(b) splice variants is similar. Functionally, these isoforms do not display large differences (Ardati et al., 1999; Palchaudhuri et al., 1999; Dautzenberg et al., 2004b). In rodents, CRF2(a) is mainly expressed in the central nervous system, while CRF2(b) is the main peripheral isoform (Lovenberg et al., 1995a; Palchaudhuri et al., 1999; Dautzenberg et al., 2004b); in humans, however, CRF2(a) is also the prevalent isoform in the periphery (Valdenaire et al., 1997; Kostich et al., 1998). In addition to these functional receptor isoforms, several non-functional CRF2 splice variants have been described. Of interest are soluble forms lacking the transmembrane domains, which have been described in rodents. These soluble splice variants are not functional receptors but could act as ligand scavengers (like the CRF-binding protein), influencing CRF signaling (Chen et al., 2005; Wu et al., 2007).

Corticotrophin-releasing factor receptors are also activated by other ligands, apart from CRF proper. Important endogenous agonists are the urocortins (UCNs). To date, three urocortin peptides have been described in mammals. UCN1 is a 40 amino acid peptide (Vaughan et al., 1995), related to the fish urotensin 1 and the amphibian sauvagine (Ichikawa et al., 1982; Lederis et al., 1982; Okawara et al., 1988; Stenzel-Poore et al., 1992). UCN2 and UCN3 were previously also designated as stresscopin-related peptide and stresscopin, respectively, and are likely to consist of 38 amino acids although lengths of 43 amino acids (for UCN2) and 40 amino acids (for UCN3) have also been proposed (Hsu and Hsueh, 2001; Lewis et al., 2001; Reyes et al., 2001). Since mammalian UCNs had not been described before 1995, the possibility of aspecificity of CRF antibodies, i.e., these antibodies possibly also stained UCNs in earlier morphological studies, should be considered. UCNs are equally or even more important ligands of CRF receptors in spite of the receptor's designation: the receptors show higher affinity for UCNs than for CRF. However, marked differences in affinity were found between CRF1 and CRF2: UCN1 binds both CRF1 and CRF2, whereas UCN2 and UCN3 only bind to CRF2. Comparison of the UCNs revealed that the affinity of UCN1 and UCN2 for CRF2 is similar but higher than that of UCN3. Furthermore, UCNs show a slightly higher affinity for CRF2(b) than for CRF2(a) (Hsu and Hsueh, 2001; Lewis et al., 2001; Reyes et al., 2001).

\section{EXPRESSION OF CRF-RELATED PEPTIDES IN THE STOMACH}

Given the apparent link between stress and GI disorders, several studies have focused on the expression of CRF-related peptides (CRF, UCNs, and CRF receptors) in the GI tract. An extensive immunohistochemical study of the guinea pig enteric nervous system showed CRF immunoreactivity - be it at very low levels - in the myenteric plexus; for example, only $\sim 0.6 \%$ of total cell bodies in the stomach (the lowest of the GI tract) was CRF positive (see below; Liu et al., 2006). CRF was present in both nerve fibers and neuronal cell bodies. The fibers were CGRP and tyrosine hydroxylase $(\mathrm{TH})$ negative and CRF was still demonstrable after 7 days of organotypic culture, indicating that these CRF-expressing fibers are of intrinsic origin. The majority of CRF-positive myenteric neurons in guinea pig displayed Dogiel type I morphology (Liu et al., 2006). In the rat gastric antrum, Porcher et al. (2006) also reported CRF-positive myenteric neuronal cell bodies and fibers, along with CRF expression in smooth muscle cells. The immunohistochemical results of this study, however, were in disagreement with the quantitative PCR data which failed to reveal CRF expression (Porcher et al., 2006). Accordingly, reverse transcriptase-PCR (RT-PCR) data also showed a lack of CRF mRNA in human gastric mucosa (Chatzaki et al., 2003).

Data on expression of UCNs in the stomach are rather scarce, with most data available for UCN1. This peptide has been found to be expressed in the gastric mucosa, in particular in parietal cells, in both human and rat (Kozicz and Arimura, 2002; Chatzaki et al., 2003). Chatzaki et al. (2004b) reported that parietal-like cells in gastric glands of the rat co-expressed CRF2 but not CRF1. UCN1 (co-localized with $\mathrm{TH}$ ) was also found in fibers of the rat gastric enteric plexus (Kozicz and Arimura, 2002; Porcher et al., 2006). In contrast to Kozicz and Arimura (2002), Porcher et al. (2006) also observed UCN1 in neuronal bodies of the gastric myenteric plexus. Finally, UCN1 was detected in serotonin (5-HT)-immunoreactive (ir) enterochromaffin cells in rat stomach. However, the latter finding is in contrast to RT-PCR data on gastric UCN1 expression in the same study as well as in an earlier report (Harada et al., 1999; Porcher et al., 2006), which the authors stated to be due to the very low level of RNA expression at the time of sampling. UCN2 expression in the stomach has been described in mouse, rat as well as in human, but only at the mRNA level (Hsu and Hsueh, 2001; Chen et al., 2004; Porcher et al., 2006). Comparison with 
other peripheral tissues in mouse revealed that gastric expression of UCN2 was low (Chen et al., 2004). In rat, Porcher et al. (2006) demonstrated comparable UCN2 levels in antrum muscle layers and mucosa. UCN3 in the stomach, finally, has been demonstrated in human tissue and, again, only at the mRNA level (Hsu and Hsueh, 2001).

Gastric expression of CRF receptors has been described in human, guinea pig, and rat. In guinea pig, CRF1-expressing neurons constituted about half of the myenteric neurons in the gastric corpus, and one-third in the antrum (Liu et al., 2005). In rat, CRF1 expression was also reported in the myenteric plexus of the antrum. However, in contrast to the data in guinea pig where no co-localization with synapsin was found, CRF1 in rat was co-localized with synaptophysin, suggestive of presynaptic expression (Porcher et al., 2006). One study reported CRF1 expression in enteroendocrine-like cells of the mucosal glands in the rat gastric corpus (Chatzaki et al., $2004 b)$. These cells did not express $\mathrm{H}^{+} / \mathrm{K}^{+}$-ATPase or somatostatin but were found in close proximity to UCN1-expressing cells. Moreover, UCN1-expressing nerve fibers have also been described in close proximity to the gastric glands hinting at a role of UCN1 in regulating gastric secretion through the CRF1 receptor (Kozicz and Arimura, 2002). Gastric expression of CRF1 was confirmed at the mRNA level in both rat and guinea pig (Liu et al., 2005; Porcher et al., 2006). In human stomach, however, CRF1 mRNA could not be detected, whereas CRF2 mRNA was detectable (Chatzaki et al., 2006). CRF2 protein expression in human was found in the mucosa, where it is possibly involved in the regulation of apoptosis, and in a few immune cells in the lamina propria (Chatzaki et al., 2006). In rat, protein expression was found in cells expressing $\mathrm{H}^{+} / \mathrm{K}^{+}$-ATPase and $\mathrm{UCN} 1$ in the mucosal glands, indicating expression in parietal cells (Chatzaki et al., 2004b). The same study also described expression of CRF2 in submucous blood vessels. CRF2, just like CRF1, was found to be co-localized with synaptophysin in the myenteric plexus of the antrum (Porcher et al., 2006). Quantitative PCR disclosed CRF2 mRNA in the mucosa and muscle layers of the rat gastric antrum, with the highest expression observed in the muscle layers (Porcher et al., 2006). A schematic overview of the expression of CRF-related peptides is given in Figure 1.

\section{EXPRESSION OF CRF-RELATED PEPTIDES IN THE SMALL INTESTINE}

In the guinea pig small intestine, half of the myenteric ganglia of the jejunum and ileum and about one-third of the duodenal myenteric ganglia contained at least one CRF-positive neuron. CRF-ir neurons, just like those in the stomach, mainly display Dogiel type I morphology (Liu et al., 2006). CRF immunoreactivity appeared to be higher in the guinea pig submucous plexus with all ganglia containing CRF-ir neurons, which accounted for about one-third of the total amount of submucous neurons. Dogiel type I was again the predominant morphological phenotype (Liu et al., 2006). The same study also investigated the chemical coding of the ileal neuronal bodies after colchicine treatment and found that CRF in myenteric neurons was co-expressed with choline acetyltransferase (ChAT), nitric oxide synthetase (NOS), and, to a lesser extent, substance P (SP; Liu et al., 2006). The neurochemical coding strongly suggests that CRF is expressed in descending interneurons and/ or motor neurons, but not in intrinsic primary afferent neurons
(IPANs; Furness, 2006). In the submucous plexus of the ileum, all CRF-ir neurons co-expressed vasoactive intestinal peptide (VIP), which together with their Dogiel type I morphology indicates that they are non-cholinergic secretomotor/vasodilator neurons (Furness, 2006; Liu et al., 2006). Other studies have focused on the rat. The first study in the rat small intestine, performed as early as 1984, described CRF-ir neurons and fibers in the duodenal myenteric plexus, but not in the submucous plexus (Wolter, 1984). The absence of CRF in the submucous plexus reported by Wolter (1984) is in contrast with later findings of la Fleur et al. (2005) who detected CRF in the nerve fibers of the submucous plexus. However, the former study did describe blood vessel-associated submucous nerve fibers in the duodenum. CRF in submucous nerve fibers has also been observed in the rat jejunum and ileum (la Fleur et al., 2005; Sand et al., 2010). In addition, the rat ileum has also been reported to contain CRF mRNA, which corroborates the immunohistochemical results, according to which CRF was located in nerve fibers of the enteric plexuses and - at low levels - also in the lamina propria and Paneth cells (la Fleur et al., 2005; Sand et al., 2010). The recent study by Sand et al. (2010) specified that these CRF-ir nerve fibers predominantly co-expressed VIP and were located in the lamina propria, circular muscle layer, and around enteric neurons. Few CRF-positive fibers were also seen around blood vessels and in the longitudinal muscle layer. In addition to CRF expression in nerve fibers, the same study also described CRF in neuronal somata of the submucous and, to a lesser extent, myenteric plexus, strongly co-localizing with VIP. Finally, some CRF-ir endocrine cells were observed in the crypts of the rat ileum (Sand et al., 2010). The only report in mouse describes CRF expression in the lamina propria and in a few epithelial cells of the ileum, at both the mRNA and the protein level (Wlk et al., 2002).Care should be exercised when interpreting the immunoreactivity that is often described in immune cells. For instance, Sand et al. (2010) reported that in their hands, CRF immunoreactivity in lamina propria immune cells persisted after preabsorption of the antibody, while in other cells it was abolished. This illustrates that proper controls should always be included, especially when dealing with immunoreactivity in immune cells.

Protein expression of UCNs in the small intestine has mainly been described in rat tissue, although there is one paper reporting UCN3 expression in the murine muscularis mucosae (Hsu and Hsueh, 2001). UCN1 was not found in rat enteric neuronal cell bodies but was co-localized with TH in fibers of the enteric nervous system, fibers around the Lieberkühn crypts and in some enteroendocrine cells in these crypts (Kozicz and Arimura, 2002). Since axonal transport had not been blocked for these stainings, expression in intrinsic neurons cannot be completely ruled out, given observations of a small population of $\mathrm{TH}$-ir intrinsic enteric neurons (Chevalier et al., 2008; Qu et al., 2008). The transcript for UCN1 was found in both enteric plexuses (Harada et al., 1999). UCN2 mRNA has been described in both rat and mouse small intestine (Chen et al., 2004; Chang et al., 2007), but the murine expression has been reported to be very low for all regions of the small intestine (Chen et al., 2004). Throughout the rat small intestine, UCN2 was detected in the epithelium, lamina propria immune cells and the enteric plexuses with the highest expression observed in the jejunum (Chang et al., 2007). In human small intestine, 

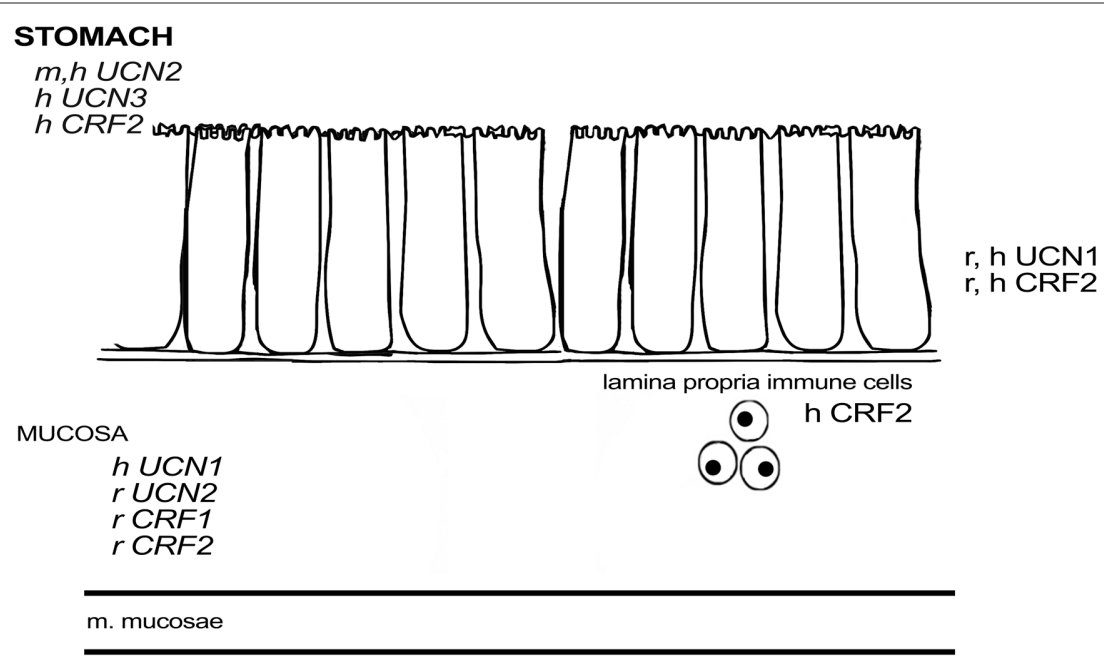

\section{SUBMUCOSA}
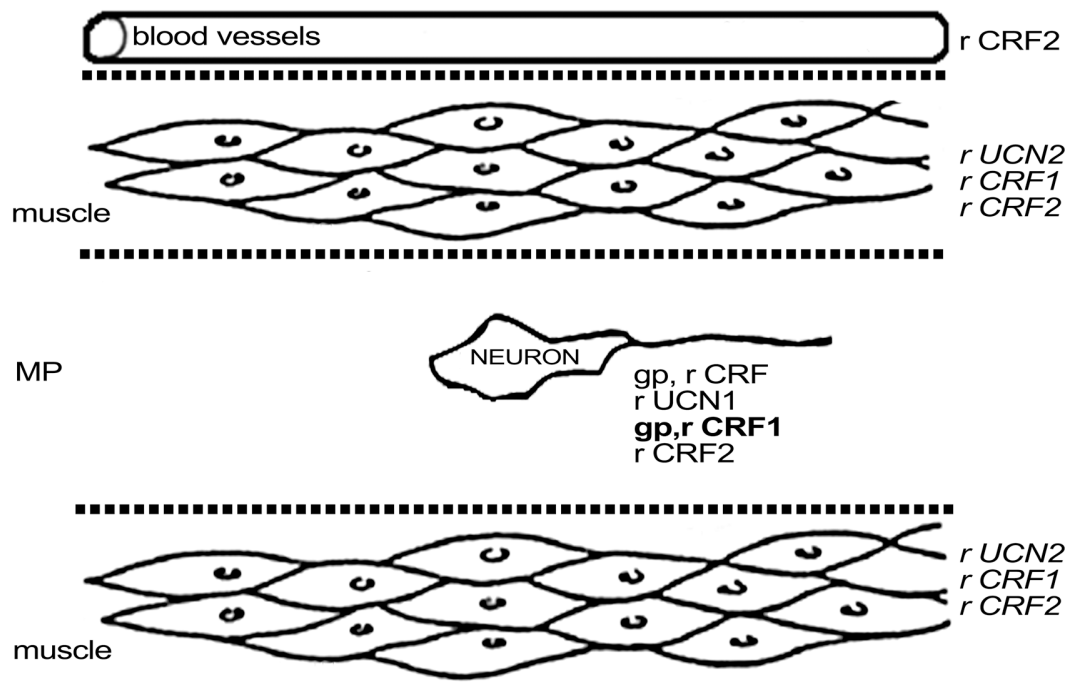

FIGURE 1 | Schematic overview of the expression of CRF-related proteins in the stomach. Regular font indicates that protein expression has been described, italic font indicates that mRNA expression has been described, bold font indicates that expression has been described at mRNA and protein level. MP, myenteric plexus; SP, submucous plexus; $r$ rat; $m$, mouse; gp, guinea pig; $h$, human; o, ovine fetus.
UCN2 mRNA was absent, while UCN3 mRNA was detected in all regions of the small intestine, except for the ileocecal area (Hsu and Hsueh, 2001).

In guinea pig, CRF1 was found to be expressed in about onethird of the myenteric neurons and half of the submucous neurons, with little variation between the different regions of the small intestine (Liu et al., 2005). CRF1 was not found in interstitial cells of Cajal, enteroendocrine cells, or muscle fibers of this species (Liu et al., 2005). Almost all enteric CRF1-ir neurons in the guinea pig ileum were cholinergic, and strong co-labeling with calbindin (CalB) was observed in the myenteric plexus (Liu et al., 2005), indicating that CRF1 is mainly expressed in IPANs, at least in the ileal myenteric plexus (Furness, 2006). In the submucous plexus of the ileum, all CalB-ir, and all SP-ir neurons also displayed CRF1, while a significant proportion of CRF1-ir neurons did not express these markers. Co-localization between CRF1 and NOS, VIP, or calretinin (CalR) was absent in the guinea pig ileum (Liu et al., 2005; Bisschops et al., 2006). The expression of CRF1 in the guinea pig is thus complementary to that of CRF and indeed Liu et al. (2005) showed that neurons with IPAN characteristics are excited by CRF. CRF signaling could thus be a basis of direct communication between enteric motorneurons and IPANs. In mouse, only one study has reported on the expression of CRF1 mRNA in cells of the lamina propria and epithelium (Wlk et al., 2002). In rat, Porcher et al. (2005) observed CRF1 in enteric neurons with Dogiel type II morphology and innerve fibers, although these findings are in contrast with the results of another study describing the absence of CRF1 in the duodenal submucosa (Chatzaki et al., 2004b). Quantitative 
PCR revealed that CRF1 expression was higher in the muscle layers and mucosa of the rat duodenum compared to the ileum (Porcher et al., 2005). As such, a species difference in CRF1 expression in muscle layers can be observed between rat and guinea pig (Liu et al., 2005). Furthermore, the regional differences in the expression level of CRF1 are opposite to those of CRF2, in which case mRNA expression was higher in the ileum, while duodenal muscle layers were devoid of CRF2 message (Porcher et al., 2005). Another study stated that there was no expression of CRF2 mRNA whatsoever in the rat duodenum, in contrast to the jejunum and ileum (Chang et al., 2007). In murine tissue, CRF2 mRNA has been found in the submucosa and at the base of the villi in the duodenum (Perrin et al., 1995) and - at low levels - also in the lamina propria and epithelium of the ileum (Wlk et al., 2002). Morphological data provide evidence for the presence of CRF2 in enteric neurons and nerve fibers in rat, co-expressing synaptophysin. These fibers displayed varicosities that encircled CRF2-negative neurons. Some CRF2 was found in the duodenal glands (Chatzaki et al., 2004b) and in 5-HT-negative epithelial cells in the villi (Porcher et al., 2005). CFR2 expression was not found the small intestine in guinea pig (Liu et al., 2005), while only a few lamina propria cells were stained in murine ileum (Wlk et al., 2002), which again points to significant species differences in CRF receptor expression. Figure 2 summarizes the available data on expression of CRF-related peptides in the small intestine.

\section{EXPRESSION OF CRF-RELATED PEPTIDES IN THE COLON}

Prepro-CRF has been described in epithelial cells, the lamina propria, and the submucosa of the rat colon (Barreau et al., 2007). The colon hosts the largest number of CRF-ir myenteric neurons of the guinea pig GI tract - albeit still a mere $2.8 \%$ of all myenteric neurons - with a predominantly Dogiel type I morphology. Likewise, the proportion of CRF-ir submucous neurons was also highest in the guinea pig colon, but in this case amounted to close to $40 \%$ of the total submucous neurons. These neurons all had Dogiel type I morphology (Liu et al., 2006). In the rat colon, CRF-ir was present in a moderate number of myenteric neurons, accounting for about $5-10 \%$ of the total myenteric neurons (Kimura et al., 2007; Sand et al., 2010). Almost $60 \%$ of the CRF-ir neurons in rat were VIPergic in both enteric plexuses. CRF-ir nerve fibers in the rat colon were also mostly VIPergic and were mainly located in the mucosa and submucous ganglia and in the circular muscle layer (Sand et al., 2010). Non-neuronal expression of CRF (co-expressed with 5-HT) was found in enteroendocrine cells in rat and human (Kawahito et al., 1994; Sand et al., 2010), and in other epithelial cells and monocytes in human (Kawahito et al., 1995). The results, however, are in contrast with other reports in which the rat colon was found to lack any CRF mRNA or proteins (Harada et al., 1999; la Fleur et al., 2005). For the rat cecum, only a very weak expression of CRF has been mentioned in the enteric plexuses (van Tol et al., 1996).

Expression of UCN1 in the rat colon is markedly higher than that of CRF and seems to be located - at least partly - in a different neuronal population (Harada et al., 1999; Kimura et al., 2007). UCN1-ir neurons constitute approximately 70 and $80 \%$ of submucous and myenteric neurons, respectively. While a large proportion of the CRF-ir neurons were VIPergic (Sand et al., 2010), UCN1 was present in most cholinergic myenteric neurons. Approximately 65\% of the serotonergic neurons also expressed UCN1 (Kimura et al., 2007). Mucosal expression of UCN1 has only been reported in very few cells of the rat colon (Kozicz and Arimura, 2002). In humans, strong UCN1 expression was observed in mononuclear cells of the lamina propria (Muramatsu et al., 2000; Bhatia and Tandon, 2005; Saruta et al., 2005), appearing after birth and increasing up to adulthood (Muramatsu et al., 2000). However, Muramatsu et al. (2000) reported that the enteric plexuses were devoid of UCN1, whereas with Saruta et al. (2005) described a weak expression in the enteric plexuses, epithelial (enterochromaffin) cells and vascular endothelium, and smooth muscle. UCN2 mRNA was absent in the human colon, very low in the murine colon, but abundant along the entire duodenal-rectal region in the rat colon (Hsu and Hsueh, 2001; Chen et al., 2004; Chang et al., 2007). Protein expression in the colon, however, was lower than in the jejunum and located in epithelial cells, lamina propria immune cells, and enteric neurons (Chang et al., 2007). The presence in epithelium and enteric neurons also holds true for the rectum, but expression levels were the lowest of the duodenal-rectal region (Chang et al., 2007). The same study also mentioned UCN2 immunoreactivity - be it faint and inconsistent - in Peyer's patches. UCN3 expression has been described in human colon, in particular in the enteric plexuses, smooth muscle, endothelium and - at a low level - also in lamina propria mononuclear cells (Hsu and Hsueh, 2001; Saruta et al., 2005). Immunohistochemical results further revealed that the UCN3 signal was localized in both enteric neurons and S-100-ir enteric glial cells. The signal was strongest in the myenteric plexus. Immunohistochemistry, unlike in situ hybridization, showed the expression of UCN3 in serotonergic enterochromaffin cells and epithelium, be it at rather low levels (Saruta et al., 2005). These contrasting results thus could arise from differences in sensitivity between the employed techniques. To our knowledge, data on UCN3 expression in rodents are currently lacking.

Expression of CRF1 mRNA and protein has been detected in the myenteric plexus in both the guinea pig and rat colon (Chatzaki et al., 2004a; Liu et al., 2005, 2010; Kimura et al., 2007; Yuan et al., 2007; O'malley et al., 2010b). In guinea pig, the signal for CRF1 was also found in the submucous plexus (Liu et al., 2005), while the data in rat are inconsistent (Chatzaki et al., 2004a; Yuan et al., 2007; O'malley et al., 2010b). Expression of CRF1 in the guinea pig colon is similar to that in the ileum, albeit with some subtle differences. Almost all CRF1-ir myenteric neurons were cholinergic, and some expressed CalB, as such resembling their counterparts in the ileum. However, about one-third of the colonic myenteric neurons was nitrergic, whereas none of the ileal CRF1-ir neurons of the myenteric plexus was nitrergic. The proportion of CRF1-ir neurons (40\%) was comparable to that in the ileum (Liu et al., 2005, 2010). Again, CRF1-ir fibers were synapsin-negative in guinea pig, indicating that the expression of CRF1 is not located presynaptically (Liu et al., 2005).The expression of CRF1 seems to be markedly higher in rat compared to guinea pig, with almost all myenteric neurons displaying CRF1 immunoreactivity (Chatzaki et al., 2004a; Yuan et al., 2007). Activation by CRF induced the neuronal activation marker c-Fos in cholinergic and nitrergic neurons with Dogiel type I morphology (Yuan et al., 2007). Interestingly, Kimura et al. (2007) showed that CRF1-ir myenteric fibers were located around UCN1-ir cell bodies. Given the high expression of UCN1, and 

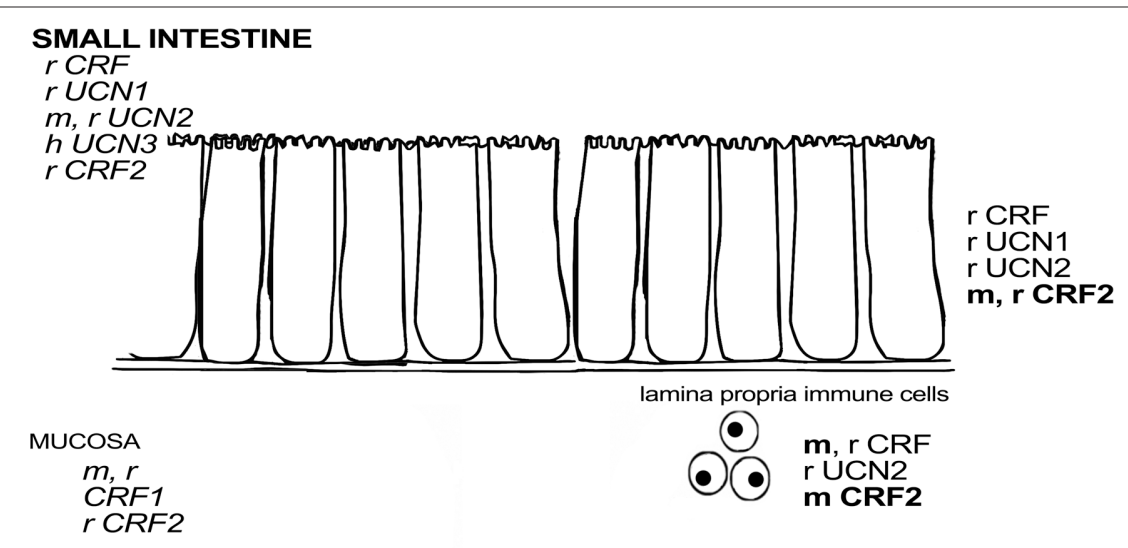

\begin{tabular}{lc}
\hline m. mucosae & m UCN3 \\
\hline
\end{tabular}

SUBMUCOSA

$m$ CRF2

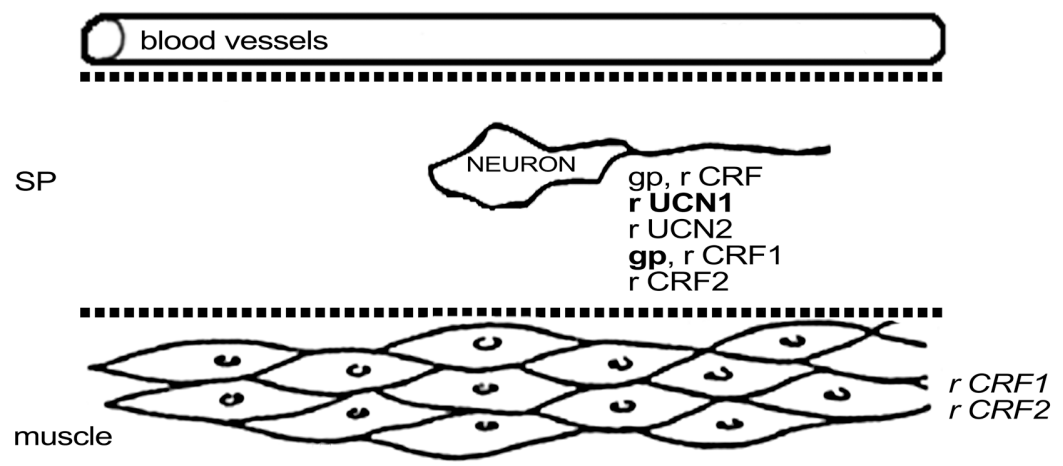

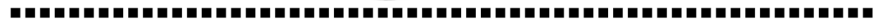

MP
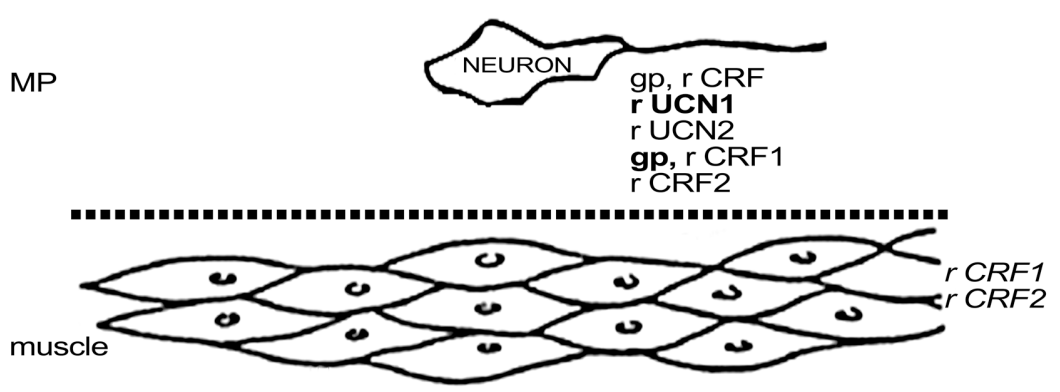

FIGURE 2 | Schematic overview of the expression of CRF-related proteins in the small intestine. Regular font indicates that protein expression has been described, italic font indicates that mRNA expression has been described, bold font indicates that expression has been described at mRNA and protein level. MP, myenteric plexus; SP, submucous plexus; $r$, rat; $m$, mouse; gp, guinea pig; $h$, human; o, ovine fetus. the highly probable co-localization of UCN1, ChAT, and 5-HT, it could be hypothesized that these (UCN1-ir) neurons, at least in rat, are mainly descending interneurons involved in secretomotor and motility reflexes that secrete UCN1 and that these neurons as such might influence the excitability of CRF1-expressing enteric fibers (Furness, 2006; Kimura et al., 2007; Yuan et al., 2007; Qu et al., 2008). Indeed, a functional study in guinea pig confirmed that $\mathrm{UCN} 1$ is capable of exciting CRF1-expressing myenteric neurons in the colon (Liu et al., 2010). Non-neuronal expression of CRF1 in rat has been reported in some lamina propria cells (Chatzaki et al., 2004a; O'malley et al., 2010a,b). One paper describes the expression of CRF1 in the distal colon of the ovine fetus, where it was expressed in muscle tissue, enteric ganglia, and goblet cells. Generally CRF1 immunoreactivity is seen to increase during gestation, especially in the enteric ganglia (Lakshmanan et al., 2008). Muramatsu et al. (2000) showed CRF1 mRNA expression in human lamina propria mononuclear cells. A more recent study by Wallon et al. (2008) on human colon biopsies also disclosed CRF1 expres- 
sion in subepithelial cells, which were identified as mast cells by co-localization with tryptase. However, these authors did not find any CRF1 on other cell types, which is in disagreement with the animal studies, although it should be mentioned that the myenteric plexus was not included in the studied biopsies. CRF2 has also been found in human lamina propria mononuclear cells, and faint CRF2 expression has been observed in epithelial cells, both at them RNA and the protein level (Muramatsu et al., 2000; Saruta et al., 2005). Furthermore, CRF2, unlike CRF1, has also been localized in the enteric plexuses, the endothelium, and vascular smooth muscle, which closely resembles the expression pattern of UCN1 and UCN3 in the human colon described in the same study (Saruta et al., 2005). In rat, the message for CRF2 has been reported in both the colon and the rectum (Chatzaki et al., 2004a; Chang et al., 2007). This expression was confirmed at the morphological level with CRF2 being located in lamina propria cells and myenteric plexus fibers again observed in close proximity to UCN1-ir cell bodies, as was also the case for CRF1 (Kimura et al., 2007; O'malley et al., 2010a,b). However, these findings are in contrast with the results of the first report on CRF receptor expression in the rat colon where goblet cells and submucosal blood vessels, but not enteric neurons or fibers, were found to be CRF2-ir (Chatzaki et al., 2004a). The neurochemical coding of the CRF2-expressing neurons in rat has not been investigated. In guinea pig, myenteric synapsin- and CRF2-expressing nerve fibers have been described, but expression in cell bodies was very low. These infrequent CRF2-ir myenteric cell bodies all displayed CalB and ChAT immunoreactivity but were negative for NOS (Liu et al., 2010), suggesting that these were IPANs (Furness, 2006). Another study did not report any CRF2 expression in the enteric plexuses of guinea pig (Bisschops et al., 2006). Finally, expression of CRF2, just like that of CRF1, was investigated in the ovine fetus: CRF2 expression in muscle layers was found to decrease with gestation, while neuronal expression was limited to fibers of unspecified origin (Lakshmanan et al., 2008). An overview of the colonic expression of CRF-related peptides is provided in Figure 3.

\section{INFLUENCE OF INFLAMMATION ON THE EXPRESSION OF CRF-RELATED PEPTIDES}

Given the apparent links between stress and GI disorders (Bhatia and Tandon, 2005), it is definitely worthwhile to investigate the GI expression of CRF-related peptides during inflammation. Although this topic has been dealt with in a number of studies, morphological data are generally still limited. The results gathered so far tend to suggest that the expression of CRF-related peptides is increased in both inflammatory animal models and IBD biopsies. In the murine ileum, CRF and CRF receptor expression were found to be increased within $1 \mathrm{~h}$ after Clostridium difficile toxin A-induced inflammation. CRF expression was mainly located on subepithelial cells, while both CRF receptors were found in both lamina propria cells and epithelial cells. This increased expression at least partially acted in a pro-inflammatory manner since blockade of CRF1 led to decreased inflammation (Wlk et al., 2002). Other animal studies all focused on the rat species. Increased CRF expression was observed in inflammatory cells, mesenchymal cells, and in the myenteric plexus, both at mRNA and protein level following a cecal inflammation induced with peptidoglycan-polysaccharides (van Tol et al., 1996). Treatment of isolated lamina propria mononuclear cells from the same model showed a proliferative effect of CRF (van Tol et al., 1996). A recent study, using an E. Coli lipopolysaccharide (LPS)induced colitis model, equally reported increased CRF levels in the enteric plexuses. At the mRNA level, CRF expression was found to be increased throughout the colonic mucosa and submucosa. The largest changes were observed in the proximal colon and mainly in samples combining submucosa and muscle layers (Yuan et al., 2010). In a 2,4,6-trinitrobenzenesulfonic acid (TNBS)-induced colitis model in rats, CRF2 expression, present on myenteric neurons and macrophages, decreased in the early phase (days 1-3) of inflammation, which is different from the situation in the murine ileum (Wlk et al., 2002; Chang et al., 2007), possibly as a consequence of species, regional or model dissimilarities. The CRF2 down regulation observed after TNBS-induced colitis in rat seems to contrast with the upregulation of the agonist UCN2, the mRNA expression of which increased in the early and late stages (days 12-15) of inflammation due to infiltration of UCN2-expressing immune cells and fibrosis by UCN2-expressing fibroblasts. Another study revealed decreased UCN2 immunoreactivity in the myenteric plexus following TNBSinduced colitis (Chang et al., 2007). This decrease in CRF2 expression might be a response compensating for the increased presence of UCN2, although this regulation remains speculative. A study by Moss et al. (2007) performed on a graft of human fetal intestine in immunodeficient (SCID) mice in which inflammation had been induced by $C$. difficile toxin $\mathrm{A}$, demonstrated increased mucosal UCN2 mRNA expression (after $6 \mathrm{~h}$ ) and upregulated mucosal CRF2 expression, which is in line with the observations made in the murine toxin A model (Wlk et al., 2002; Moss et al., 2007). Although it is an interesting method to study the intrinsic inflammatory process in the human intestine, this model naturally lacks a number of extrinsic factors influencing inflammation.

All other data on the expression of CRF-related peptides during inflammation were gathered from human biopsies. In Helicobacter pylori-induced gastritis, no induction of gastric CRF expression could be found (Chatzaki et al., 2003). However, a marked increase in UCN1 expression was found in epithelial and inflammatory cells. The highest increase in UCN1 expression was observed during regression and correlated well with the successful eradication of the $H$. pylori infection, leading the authors to hypothesize a protective role for UCN1 (Chatzaki et al., 2003). This finding again indicates that CRF itself may not be the main agonist for the CRF receptors, at least not in the stomach. Increased CRF expression was observed in monocytes, but not in epithelial cells, in UC biopsies compared to healthy samples (Kawahito et al., 1995). Again, other CRF receptor agonists were also reported. UCN1 was present in lamina propria plasma cells, but not in macrophages, in UC biopsies where it was partially co-expressed with CRF1 and CRF2 (Saruta et al., 2004). The UCN1 levels were found to be lower in biopsies from glucocorticoid-treated patients and higher in case of more severe inflammation (Saruta et al., 2004). The same study also disclosed UCN1 in mucosal cells, some of which were identified as enterochromaffin cells (Saruta et al., 2004). Another study on UC and also CD biopsies, reported increased epithelial expression of both UCN2 and CRF2 in regions with active colitis compared to non-inflamed regions of the same patients (Moss et al., 2007). The changes in the expression of CRF-related peptides are summarized in Table 1. 


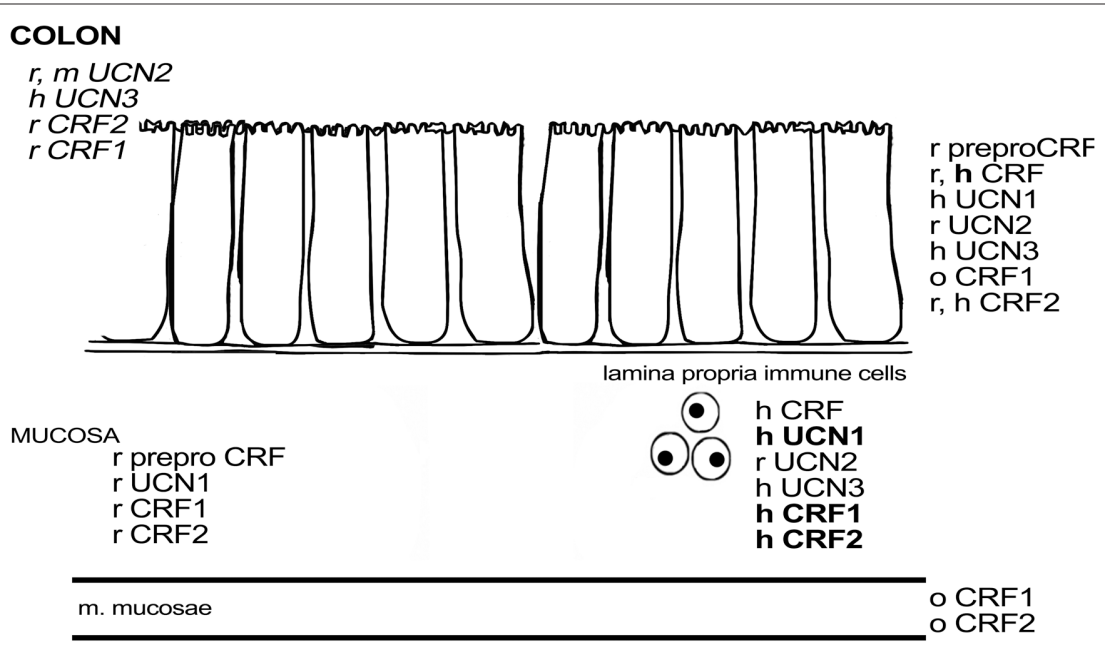

\section{SUBMUCOSA}

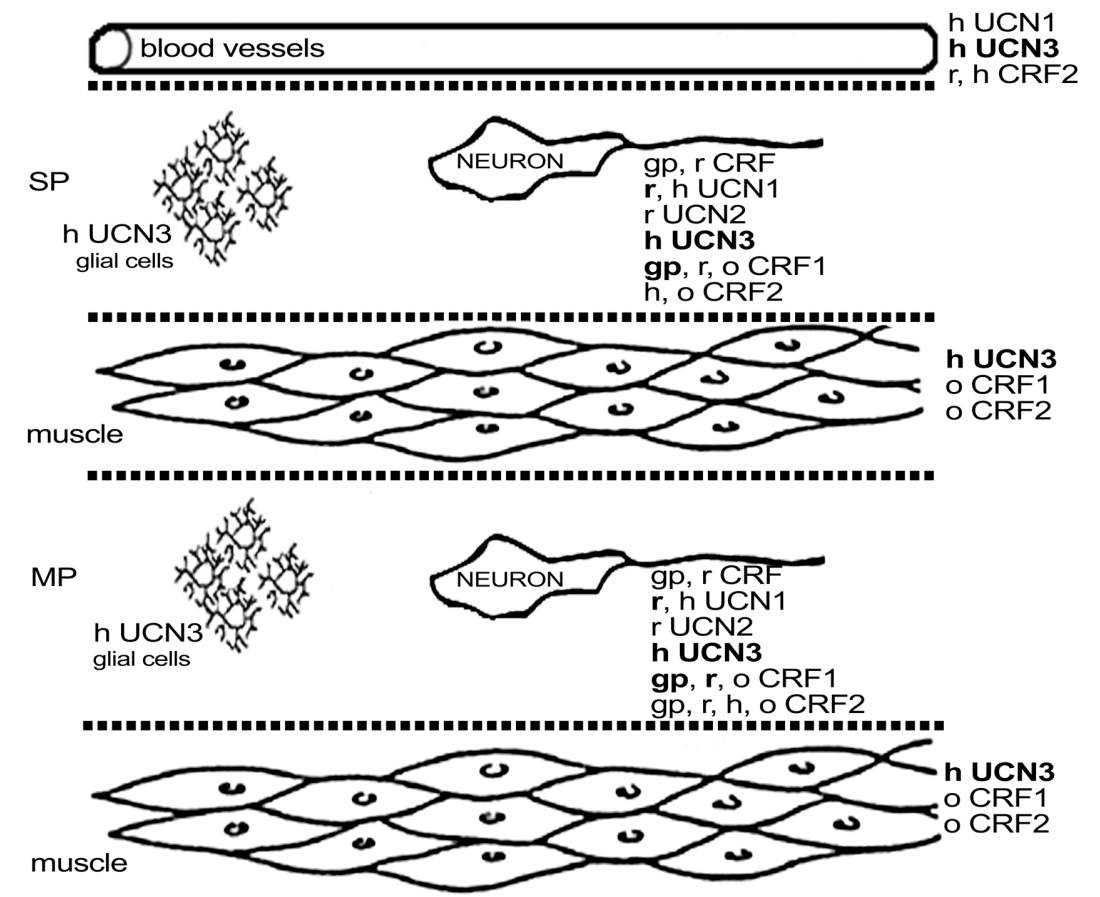

FIGURE 3 | Schematic overview of the expression of CRF-related proteins in the colon. Regular font indicates that protein expression has been described, italic font indicates that mRNA expression has been described, bold font indicates that expression has been described at mRNA and protein level. MP, myenteric plexus; SP, submucous plexus; r, rat; m, mouse; gp, guinea pig; $h$, human; o, ovine fetus.

\section{ROLE OF CRF-RELATED PEPTIDES IN GI INFLAMMATION}

Apart from one report on TNBS-induced colitis in rats (Chang et al., 2007), there seems to be agreement in the literature that the components of the CRF signaling pathway increase with inflammation. In addition, there are plenty of indications that changes in the expression pattern of CRF-related peptides may have an important impact on GI functions. Functional studies clearly revealed that activation of CRF receptors often results in contrasting effects, depending on the GI region. For example, activation of CRF2 inhibits gastric emptying and ileal contraction (Pappas et al., 1985; Nozu et al., 1999; Wang et al., 2001; Martinez et al., 2002; Porcher et al., 2005), whereas CRF1 activation stimulates duodenal contractions and colonic motor activity (Mancinelli et al., 1998; Maillot et al., 2000; Porcher et al., 2005; Kimura et al., 2007; Yuan et al., 2007). In rat, CRF1 promotes while CRF2 inhibits colonic hypersensitivity (Million et al., 2003, 2006; Greenwood-Van Meerveld et al., 2005). The effects of CRF receptor signaling on immune components seem to involve several cell types, and often have an impact on the cytokine profile. Although some data originate from regions other than the GI tract, it is nonetheless clear that the role of CRF-related peptides in GI inflammation needs further 
Table 1 | Changes in expression of CRF-related peptides in the inflamed GI tract.

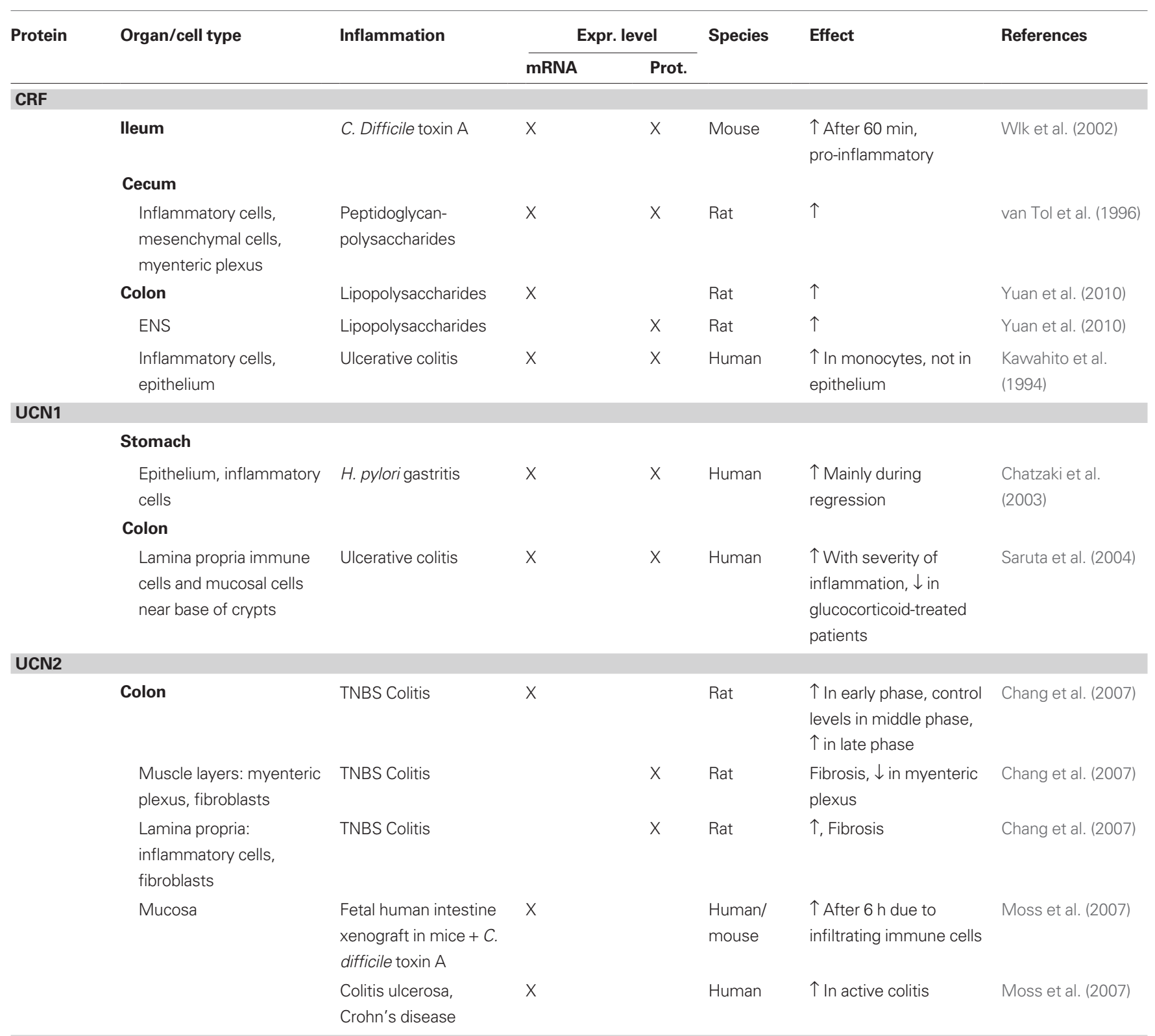

CRF1

lleum

\begin{tabular}{|c|c|c|c|c|c|}
\hline $\begin{array}{l}\text { Lamina propria and } \\
\text { epithelium }\end{array}$ & C. difficile toxin A & $x$ & Mouse & $\uparrow$ After 30-60 min. & Wlk et al. (2002) \\
\hline Colon & & & & & \\
\hline $\begin{array}{l}\text { Lamina propria immune } \\
\text { cells }\end{array}$ & Ulcerative colitis & $x$ & & $\uparrow$ & Saruta et al. (2004) \\
\hline
\end{tabular}

CRF2

\section{Ileum}

\begin{tabular}{|c|c|c|c|c|c|c|}
\hline $\begin{array}{l}\text { Lamina propria and } \\
\text { epithelium }\end{array}$ & C. difficile toxin A & $x$ & $x$ & Mouse & $\uparrow$ After 30-60 min. & Wlk et al. (2002) \\
\hline ;olon & TNBS colitis & $x$ & & & $\begin{array}{l}\downarrow \text { In early phase, control } \\
\text { levels in middle phase } \\
\text { and late phase }\end{array}$ & Chang et al. (2007) \\
\hline
\end{tabular}


Table 1 | Continued

\begin{tabular}{|c|c|c|c|c|c|c|c|}
\hline \multirow[t]{2}{*}{ Protein } & \multirow[t]{2}{*}{ Organ/cell type } & \multirow[t]{2}{*}{ Inflammation } & \multicolumn{2}{|c|}{ Expr. level } & \multirow[t]{2}{*}{ Species } & \multirow[t]{2}{*}{ Effect } & \multirow[t]{2}{*}{ References } \\
\hline & & & mRNA & Prot. & & & \\
\hline & Myenteric plexus & TNBS colitis & & $X$ & Rat & $\downarrow$ & Chang et al. (2007) \\
\hline & $\begin{array}{l}\text { Lamina propria immune } \\
\text { cells }\end{array}$ & Ulcerative colitis & $x$ & & Human & $\uparrow$ & Saruta et al. (2004) \\
\hline & & TNBS colitis & & $X$ & Rat & $\begin{array}{l}\text { Infiltrating } \\
\text { macrophages, } \\
\text { decreased after early } \\
\text { stage }\end{array}$ & \\
\hline & Mucosa & $\begin{array}{l}\text { Fetal human intestine } \\
\text { xenograft in mice }+C \text {. } \\
\text { difficile toxin } A\end{array}$ & $x$ & & $\begin{array}{l}\text { Human/ } \\
\text { mouse }\end{array}$ & $\uparrow$ After $6 \mathrm{~h}$ & Moss et al. (2007) \\
\hline & & $\begin{array}{l}\text { Colitis ulcerosa, } \\
\text { Crohn's disease }\end{array}$ & $x$ & $X$ & Human & $\uparrow$ In active colitis & Moss et al. (2007) \\
\hline
\end{tabular}

investigation. It is known that CRF leads to increased colonic permeability in rats (Santos et al., 1999; Saunders et al., 2002), a potential pro-inflammatory event. Further research has revealed that this effect is at least in part mediated by activation of mast cells through a CRF receptor-dependent mechanism, leading to the release of nerve growth factor (NGF; Castagliuolo et al., 1996; Eutamene et al., 2003; Barreau et al., 2007; Teitelbaum et al., 2008; Wallon et al., 2008). A study with an in vitro model of endothelial cells showed that CRF influences endothelial activation depending on the cellular genotype, and it was hypothesized that CRF1 acts anti-inflammatory by counteracting the effect of pro-inflammatory cytokines, while CRF2 potentiates this pro-inflammatory effect (Cantarella et al., 2001), which again points to a contrasting function of these receptors. The pro-inflammatory capacity of CRF2 has also been described in human colonocyte cell lines where CRF2 activation by UCN2 resulted in induction of NF- $\kappa B$ and subsequent increased release of the chemoattractants interleukin 8 (IL-8) and monocyte chemoattractant protein 1 (MCP-1; Kokkotou et al., 2006; Moss et al., 2007). As discussed before, production of CRF2 and UCN2 is increased in human colitis, an effect that could be mimicked in these colonocyte cell lines by stimulation with inflammatory agents, such as TNFo and C. difficile toxin A (Moss et al., 2007). In vitro treatment of murine macrophages with CRF receptor agonists leads to the anti-inflammatory inhibition of TNF $\alpha$ release in the early stages of the inflammatory response, but to increased TNF $\alpha$ transcription and release in the late stages (Tsatsanis et al., 2007). An earlier study from the same group also attributed antiinflammatory potency to CRF2 through the induction of macrophage apoptosis (Tsatsanis et al., 2005). Additionally, the transcription and expression of the toll-like receptor (Tlr) four in macrophages could be increased by stimulating CRF2 (Tsatsanis et al., 2006). Although these data clearly show that Tlr4-induced macrophage activation is stimulated by CRF2, caution should be exercised when extrapolating these results to the in vivo situation considering the effects of Tlr4 on the entire inflammatory process. Indeed, the in vivo data on the Tlr attribute an important role in intestinal immune homeostasis to these receptors (Cario and Podolsky, 2005). Deficiency in their signaling pathways - in particular in the case of Tlr4 - leads to increased intes- tinal inflammation in animal models (Rakoff-Nahoum et al., 2004; Araki et al., 2005; Rakoff-Nahoum et al., 2006) and is associated with IBD pathology in humans (De Jager et al., 2007). A recent study employing a dextran sulfate sodium (DSS)-induced colitis model in mouse showed that CRF-deficient mice have a lower expression of Tlr4 before the onset of inflammation and that inflammation is more severe in CRF-deficient mice. This effect on inflammation appears not to be due to the decreased glucocorticoid levels observed in these mice (Chaniotou et al., 2010). Another recently published paper using the murine DSS-induced colitis model again disclosed a contrasting influence at the receptor level: CFR1 knockout $\left(\mathrm{CRF}^{-/-}\right)$mice showed decreased inflammation, while $\mathrm{CRF} 2^{-/-}$mice displayed increased intestinal inflammation, an effect that could be mimicked by antagonizing the receptors in wildtype mice. This study, however, did not investigate Tlr expression (Im et al., 2010). Although these data suggest an in vivo anti-inflammatory effect of CRF2, other results show a pro-inflammatory influence, possibly depending on the type of inflammation. CRF2 knockout has been shown to lead to attenuated inflammation in C. difficile toxin A-induced ileal inflammation. The pro-inflammatory role of CRF2 in this study was largely mediated by chemokine induction, since blocking this receptor reduced IL-6, MCP1 , and keratinocyte chemokine levels and neutrophil infiltration (Kokkotou et al., 2006). The pro-inflammatory influence of CRF was underscored in another study from the same group, which showed that $\mathrm{CRF}^{-1-}$ mice developed less severe inflammation. The authors linked the CRF deficiency to the absence of a toxin A-induced increase in SP levels (Anton et al., 2004). Wlk et al. (2002) demonstrated that CRF receptor antagonists reduced the rise in TNF $\alpha$ and IL-1 $\beta$ and gave rise to histological changes in $C$. difficile toxin A-induced ileitis. They showed that part of this effect is mediated through the CRF1 receptor, but did not exclude involvement of CRF2, which has indeed been reported by Kokkotou et al. (2006; see above). The pro-inflammatory effect of CRF in C. difficile toxin A-induced ileal inflammation was also reported in rat (la Fleur et al., 2005). Interestingly, this study showed that intestinal CRF knockdown, but not UCN2 knockdown, completely ablated inflammation and increased CRF1 expression in inflamed tissue, which suggests an important role of CRF1 in the 
pro-inflammatory effect of CRF in rat. In murine TNBS-induced colitis, CRF knockout also reduced inflammation with a decline in local IL-1 $\beta$ upregulation (Gay et al., 2008). Surprisingly, these effects of CRF are in contrast to reports on UCN1: UCN1, which binds to the same receptors as CRF - even with higher affinity - has been ascribed anti-inflammatory properties. Two studies by Gonzalez-Rey et al. (2006a,b), who used an endotoxemia model or TNBS-induced colitis in the mouse, revealed an influence of UCN1 on the intestinal cytokine profile. Treatment of endotoxemic animals with UCN1 successfully ablated histological changes and reduced several pro-inflammatory cytokines and chemokines, yet also increased the levels of the anti-inflammatory IL-10, systemically as well as locally, including in the small intestine (Gonzalez-Rey et al., 2006a). Comparable results were obtained in TNBS-induced colitis with the induction of a clear anti-inflammatory cytokine profile that promoted regulatory $\mathrm{T}$ cell responses but reduced Th1 responses after treatment with UCN1 (Gonzalez-Rey et al., 2006b). The contrasting results between CRF and UCN1, which both act on the same receptors, may be attributed to their different distribution patterns (see above), which would imply a tightly regulated interplay between different CRF-related peptides, all contributing to a delicate balance that influences the intestinal immune response. A final pathway in which inflammation is influenced through CRF receptor signaling, pertains to the effect CRF receptors have on angiogenesis. The effects of the two receptors on intestinal angiogenesis are again opposite to one another. During DSS-induced colitis, knocking out CRF1 or CRF2 decreased or increased microvascular density, respectively. This effect was associated with a decrease (for $\mathrm{CRF}^{-/-}$) or an increase (for $\mathrm{CRF}^{-{ }^{-}}$) in vascular endothelial growth factor (VEGF) 1 compared to inflammation in control mice (Im et al., 2010). This finding leads to the conclusion that CRF1 acts pro-angiogenic, while CRF2 is antiangiogenic. This anti-angiogenic property of CRF2 not only holds true during inflammation, but is also important for tonic regulation of angiogenesis (Bale et al., 2002).

\section{REFERENCES}

Anton, P. M., Gay, J., Mykoniatis, A., Pan, A., O’Brien, M., Brown, D., Karalis, K., and Pothoulakis, C. (2004). Corticotropin-releasing hormone (CRH) requirement in Clostridium difficile toxin A-mediated intestinal inflammation. Proc. Natl. Acad. Sci. U.S.A. 101, 8503-8508.

Arai, M., Assil, I. Q., and Abou-Samra, A. B. (2001). Characterization of three corticotropin-releasing factor receptors in catfish: a novel third receptor is predominantly expressed in pituitary and urophysis. Endocrinology 142, 446-454.

Araki, A., Kanai, T., Ishikura, T., Makita, S., Uraushihara, K., Iiyama, R., Totsuka, T., Takeda, K., Akira, S., and Watanabe, M. (2005). MyD88-deficient mice develop severe intestinal inflammation in dextran sodium sulfate colitis. J. Gastroenterol. 40, 16-23.

Ardati, A., Goetschy, V., Gottowick, J., Henriot, S., Valdenaire, O., Deuschle, U., and Kilpatrick, G. J.

\section{CONCLUDING REMARKS}

Numerous studies clearly demonstrate that CRF, CRF-related peptides and their receptors are widely distributed throughout the GI tract. However, important species differences in the expression patterns of these peptides and receptors were found at the cellular level. Moreover, characterization of the exact cellular (sub)type in which these peptides and their receptors are expressed is often lacking, especially in case of enteric neurons and immune cells. It is nevertheless clear that signaling of and through CRF-related peptides can have an important influence on the course of (GI) inflammation. CRF is known as an important stress-related peptide in the central nervous system, but may definitely claim a role in the periphery as well. The influence of CRF signaling on intestinal sensitivity, permeability and GI transit contributes to symptoms in IBD, while effects on immune cell activation, cytokine release and angiogenesis directly act on the course of inflammation. It should be emphasized, however, that UCNs are likely to play an at least equally important role. The differences in outcome depending on the inflammation model, activated receptors and involved ligands suggest that the signaling pathways of CRF-related peptides form an interacting and finely balanced system. Disturbances in this balance likely contribute to GI inflammatory disorders and manipulation of this system could open up new treatment options for these disorders. Further research remains necessary to gain full insight into the pathways involved, but the available data certainly warrant future efforts in unraveling the role of CRF-related peptides in GI inflammation.

\section{ACKNOWLEDGMENTS}

This work is funded through FWO project G.0179.08 and a TOPBOF project of the University of Antwerp (to Dirk Adriaensen and Jean-Pierre Timmermans). The authors would like to thank D. Vindevogel for carefully proofreading our manuscript and D. De Rijck for the construction of the figures.

regulator of CRF and related peptides Front. Neuroendocrinol. 16, 362-382.

Bhatia, V., and Tandon, R. K. (2005). Stress and the gastrointestinal tract. J. Gastroenterol. Hepatol. 20, 332-339. Bisschops, R., Vanden Berghe, P., Sarnelli, G., Janssens, J., and Tack, J. (2006). CRF-induced calcium signaling in guinea pig small intestine myenteric neurons involves CRF-1 receptors and activation of voltage-sensitive calcium channels. Am. J. Physiol. Gastrointest. Liver Physiol. 290, G1252-G1260.

Blank, T., Nijholt, I., Grammatopoulos, D. K., Randeva, H. S., Hillhouse, E. W., and Spiess, J. (2003). Corticotropinreleasing factor receptors couple to multiple G-proteins to activate diverse intracellular signaling pathways in mouse hippocampus: role in neuronal excitability and associative learning. $J$. Neurosci. 23, 700-707.

Brar, B. K., Chen, A., Perrin, M. H., and Vale, W. (2004). Specificity and regulation of extracellularly regulated kinase $1 / 2$ phosphorylation through corticotropin-releasing factor $(\mathrm{CRF})$ receptors 1 and 2 beta by the CRF/urocortin family of peptides. Endocrinology 145, 1718-1729.

Camara, R. J., Ziegler, R., Begre, S., Schoepfer,A.M., and von, K. R. (2009). The role of psychological stress in inflammatory bowel disease: quality assessment of methods of 18 prospective studies and suggestions for future research. Digestion 80, 129-139.

Cantarella, G., Lempereur, L., Lombardo, G., Chiarenza,A., Pafumi, C., Zappala, G., and Bernardini, R. (2001). Divergent effects of corticotropin releasing hormone on endothelial cell nitric oxide synthase are associated with different expression of CRH type 1 and 2 receptors. Br. J. Pharmacol. 134, 837-844.

Cario, E., and Podolsky, D. K. (2005). Intestinal epithelial TOLLerance versus inTOLLerance of commensals. Mol. Immunol. 42, 887-893.

Castagliuolo, I., Lamont, J. T., Qiu, B., Fleming, S. M., Bhaskar, K. R., 
Nikulasson, S. T., Kornetsky, C., and Pothoulakis, C. (1996). Acute stress causes mucin release from rat colon: role of corticotropin releasing factor and mast cells. Am. J. Physiol. 271(5 Pt 1), G884-G892.

Chang, J., Hoy, J. J., Idumalla, P. S., Clifton, M.S., Pecoraro, N.C., and Bhargava,A. (2007). Urocortin 2 expression in the rat gastrointestinal tract under basal conditions and in chemical colitis. Peptides 28, 1453-1460.

Chaniotou, Z., Giannogonas, P., Theoharis, S., Teli, T., Gay, J., Savidge, T., Koutmani, Y., Brugni, J., Kokkotou, E., Pothoulakis, C., and Karalis, K. P. (2010). Corticotropin-releasing factor regulates TLR4 expression in the colon and protects mice from colitis. Gastroenterology 139, 2083-2092.

Chatzaki, E., Charalampopoulos, I., Leontidis, C., Mouzas, I. A., Tzardi, M., Tsatsanis, C., Margioris, A. N., and Gravanis, A. (2003). Urocortin in human gastric mucosa: relationship to inflammatory activity. J. Clin. Endocrinol. Metab. 88, 478-483.

Chatzaki, E., Crowe, P. D., Wang, L., Million, M., Tache, Y., and Grigoriadis, D.E. (2004a). CRF receptor type 1 and 2 expression and anatomical distribution in the rat colon. J. Neurochem. 90, 309-316.

Chatzaki, E., Murphy, B. J., Wang, L., Million, M., Ohning, G. V., Crowe, P. D., Petroski, R., Tache, Y., and Grigoriadis, D.E. (2004b). Differential profile of CRF receptor distribution in the rat stomach and duodenum assessed by newly developed CRF receptor antibodies. J. Neurochem. 88, 1-11.

Chatzaki, E., Lambropoulou, M., Constantinidis, T. C., Papadopoulos, N., Tache, Y., Minopoulos, G., and Grigoriadis, D. E. (2006). Corticotropin-releasing factor (CRF) receptor type 2 in the human stomach: protective biological role by inhibition of apoptosis. J. Cell. Physiol. 209, 905-911.

Chen, A., Blount, A., Vaughan, J., Brar, B., and Vale, W. (2004). Urocortin II gene is highly expressed in mouse skin and skeletal muscle tissues: localization, basal expression in corticotropin-releasing factor receptor (CRFR) 1- and CRFR2-null mice, and regulation by glucocorticoids. Endocrinology 145, 2445-2457.

Chen, A. M., Perrin, M. H., Digruccio, M. R., Vaughan, J. M., Brar, B. K., Arias, C. M., Lewis, K. A., Rivier, J. E., Sawchenko, P. E., and Vale, W. W. (2005). A soluble mouse brain splice variant of type 2 alpha corticotropinreleasing factor (CRF) receptor binds ligands and modulates their activity.
Proc. Natl. Acad. Sci. U.S.A. 102, 2620-2625.

Chevalier, J., Derkinderen, P., Gomes, P., Thinard, R., Naveilhan, P., Vanden Berghe, P., and Neunlist, M. (2008). Activity-dependent regulation of tyrosine hydroxylase expression in the enteric nervous system. J. Physiol. 586, 1963-1975.

Dautzenberg, F. M., Gutknecht, E., Van der Linden, I., Olivares-Reyes, J. A., Durrenberger, F., and Hauger, R. L. (2004a). Cell-type specific calcium signaling by corticotropin-releasing factor type 1 (CRF1) and 2a (CRF2(a)) receptors: phospholipase $\mathrm{C}$-mediated responses in human embryonic kidney 293 but not SK-N-MC neuroblastoma cells. Biochem. Pharmacol.68, 1833-1844.

Dautzenberg, F. M., Higelin, J., Wille, S., and Brauns, O. (2004b). Molecular cloning and functional expression of the mouse CRF2(a) receptor splice variant. Regul. Pept. 121, 89-97.

Dautzenberg, F. M., Kilpatrick, G. J., Hauger, R. L., and Moreau, J. (2001). Molecular biology of the CRH receptors - in the mood. Peptides 22, 753-760.

De Jager, P. L., Franchimont, D., Waliszewska, A., Bitton, A., Cohen, A., Langelier, D., Belaiche, J., Vermeire, S., Farwell, L., Goris, A., Libioulle, C., Jani, N., Dassopoulos, T., Bromfield, G. P., Dubois, B., Cho, J. H., Brant, S. R., Duerr, R. H., Yang, H., Rotter, J. I., Silverberg, M. S., Steinhart, A. H., Daly, M. J., Podolsky, D. K., Louis, E., Hafler, D. A., and Rioux, J. D. (2007). The role of the toll receptor pathway in susceptibility to inflammatory bowel diseases. Genes Immun. 8, 387-397.

Eutamene, H., Theodorou, V., Fioramonti, J., and Bueno, L. (2003). Acute stress modulates the histamine content of mast cells in the gastrointestinal tract through interleukin- 1 and corticotropin-releasing factor release in rats. $J$. Physiol. 553(Pt 3), 959-966.

Furness, J. B. (2006). The Enteric Nervous System. Oxford: Blackwell Publishing.

Furutani, Y., Morimoto, Y., Shibahara, S., Noda, M., Takahashi, H., Hirose, T., Asai, M., Inayama, S., Hayashida, H., Miyata, T., and Numa, S. (1983). Cloning and sequence analysis of cDNA for ovine corticotropinreleasing factor precursor. Nature 301, 537-540.

Gallagher, J. P., Orozco-Cabal, L. F., Liu, J., and Shinnick-Gallagher, P. (2008). Synaptic physiology of central CRH system. Eur. J. Pharmacol. 583, 215-225.

Gay, J., Kokkotou, E., O’Brien, M., Pothoulakis, C., and Karalis, K. P. (2008). Corticotropin-releasing hormone deficiency is associated with reduced local inflammation in a mouse model of experimental colitis. Endocrinology 149, 3403-3409.

Gonzalez-Rey, E., Chorny, A., Varela, N., Robledo, G., and Delgado, M. (2006a). Urocortin and adrenomedullin prevent lethal endotoxemia by downregulating the inflammatory response. Am. J. Pathol. 168, 1921-1930.

Gonzalez-Rey, E., Fernandez-Martin, A. Chorny, A., and Delgado, M. (2006b). Therapeutic effect of urocortin and adrenomedullin in a murine model of Crohn's disease. Gut 55, 824-832.

Greenwood-Van Meerveld, B., Johnson, A. C., Cochrane, S., Schulkin, J., and Myers, D. A. (2005). Corticotropinreleasing factor 1 receptor-mediated mechanisms inhibit colonic hypersensitivity in rats. Neurogastroenterol. Motil. 17, 415-422.

Gross, K. J., and Pothoulakis, C. (2007). Role of neuropeptides in inflammatory bowel disease. Inflamm. Bowel Dis. 13, 918-932.

Gutknecht, E., Van der Linden, I., Van Kolen, K., Verhoeven, K. F., Vauquelin, G., and Dautzenberg, F. M. (2009). Molecular mechanisms of corticotropin-releasing factor receptor-induced calcium signaling. Mol. Pharmacol. 75, 648-657.

Gutknecht, E., Vauquelin, G., and Dautzenberg, F. M. (2010). Corticotropin-releasing factor receptors induce calcium mobilization through cross-talk with Gq-coupled receptors. Eur. J. Pharmacol. 642, 1-9.

Harada, S., Imaki, T., Naruse, M., Chikada, N., Nakajima, K., and Demura, H. (1999). Urocortin mRNA is expressed in the enteric nervous system of the rat. Neurosci. Lett. 267, 125-128.

Hauger, R. L., Grigoriadis, D. E., Dallman, M. F., Plotsky, P. M., Vale, W.W., and Dautzenberg, F. M. (2003). International Union of Pharmacology. XXXVI. Current status of the nomenclature for receptors for corticotropinreleasing factor and their ligands. Pharmacol. Rev. 55, 21-26.

Hillhouse, E.W., and Grammatopoulos, D. K. (2006). The molecular mechanisms underlying the regulation of the biological activity of corticotropin-releasing hormone receptors: implications for physiology and pathophysiology. Endocr. Rev. 27, 260-286.

Hisamatsu, T., Inoue, N., Yajima, T., Izumiya, M., Ichikawa, H., and Hibi, T. (2007). Psychological aspects of inflammatory bowel disease. $J$. Gastroenterol. 42(Suppl. 17), 34-40.

Hsu, S. Y., and Hsueh, A. J. (2001). Human stresscopin and stresscopin-related peptide are selective ligands for the type
2 corticotropin-releasing hormone receptor. Nat. Med. 7, 605-611.

Ichikawa, T., McMaster, D., Lederis, K., and Kobayashi, H. (1982). Isolation and amino acid sequence of urotensin I, a vasoactive and ACTH-releasing neuropeptide, from the carp (Cyprinus carpio) urophysis. Peptides 3, 859-867.

Im, E., Rhee, S. H., Park, Y. S., Fiocchi, C., Tache, Y., and Pothoulakis, C. (2010). Corticotropin-releasing hormone family of peptides regulates intestinal angiogenesis. Gastroenterology 138, 2457-2467.

Karteris, E., Markovic, D., Chen, J., Hillhouse, E. W., and Grammatopoulos, D. K. (2010). Identification of a novel corticotropinreleasing hormone type 1beta-like receptor variant lacking Exon 13 in human pregnant myometrium regulated by estradiol-17beta and progesterone. Endocrinology 151,4959-4968.

Kawahito, Y., Sano, H., Kawata, M., Yuri, K., Mukai, S., Yamamura, Y., Kato, H., Chrousos, G. P., Wilder, R. L., and Kondo, M. (1994). Local secretion of corticotropin-releasing hormone by enterochromaffin cells in human colon. Gastroenterology 106, 859-865.

Kawahito, Y., Sano, H., Mukai, S., Asai, K., Kimura, S., Yamamura, Y., Kato, H., Chrousos, G. P., Wilder, R. L., and Kondo, M. (1995). Corticotropin releasing hormone in colonic mucosa in patients with ulcerative colitis. Gut 37, 544-551.

Kiank, C., Tache, Y., and Larauche, M. (2010). Stress-related modulation of inflammation in experimental models of bowel disease and post-infectious irritable bowel syndrome: role of corticotropin-releasing factor receptors. Brain Behav. Immun. 24, 41-48.

Kimura, T., Amano, T., Uehara, H., Ariga, H., Ishida, T., Torii, A., Tajiri, H., Matsueda, K., and Yamato, S. (2007). Urocortin I is present in the enteric nervous system and exerts an excitatory effect via cholinergic and serotonergic pathways in the rat colon. Am. J. Physiol. Gastrointest. Liver Physiol.293, G903-G910.

Kokkotou, E., Torres, D., Moss, A. C., O’Brien, M., Grigoriadis, D. E., Karalis, K., and Pothoulakis, C. (2006). Corticotropin-releasing hormone receptor 2-deficient mice have reduced intestinal inflammatory responses. $J$. Immunol. 177, 3355-3361.

Kostich, W. A., Chen, A., Sperle, K., and Largent, B.L. (1998). Molecular identification and analysis of a novel human corticotropin-releasing factor (CRF) receptor: the CRF2gamma receptor. Mol. Endocrinol. 12, 1077-1085.

Kozicz, T., and Arimura, A. (2002). Distribution of urocortin in the rat's 
gastrointestinal tract and its colocalization with tyrosine hydroxylase. Peptides 23, 515-521.

Kyrou, I., and Tsigos, C. (2009). Stress hormones: physiological stress and regulation of metabolism. Curr. Opin. Pharmacol. 9, 787-793.

la Fleur, S. E., Wick, E. C., Idumalla, P. S., Grady, E. F., and Bhargava, A. (2005). Role of peripheral corticotropinreleasing factor and urocortin II in intestinal inflammation and motility in terminal ileum. Proc. Natl. Acad. Sci. U.S.A. 102, 7647-7652.

Lakshmanan, J., Magee, T. R., Richard, J. D., Liu, G. L., Salido, E., Sugano, S. K., Ferrini, M., and Ross, M. G. (2008). Localization and gestation-dependent pattern of corticotrophin-releasing factor receptor subtypes in ovine fetal distal colon. Neurogastroenterol. Motil. 20, 1328-1339.

Larauche, M., Kiank, C., and Tache, Y. (2009). Corticotropin releasing factor signaling in colon and ileum: regulation by stress and pathophysiological implications. J. Physiol. Pharmacol. 60(Suppl. 7), 33-46.

Lederis, K., Letter, A., McMaster, D., Moore, G., and Schlesinger, D. (1982). Complete amino acid sequence of urotensin I, a hypotensive and corticotropin-releasing neuropeptide from Catostomus. Science 218, 162-165.

Lewis, K., Li, C., Perrin, M. H., Blount, A., Kunitake, K., Donaldson, C., Vaughan, J., Reyes, T. M., Gulyas, J., Fischer, W., Bilezikjian, L., Rivier, J., Sawchenko, P. E., and Vale, W. W. (2001). Identification of urocortin III, an additional member of the corticotropin-releasing factor (CRF) family with high affinity for the CRF2 receptor. Proc. Natl. Acad. Sci. U.S.A. 98, 7570-7575.

Liu, S., Gao, N., Hu, H. Z., Wang, X., Wang, G. D., Fang, X., Gao, X., Xia, Y., and Wood, J. D. (2006). Distribution and chemical coding of corticotropin-releasing factor-immunoreactive neurons in the guinea pig enteric nervous system. J. Comp. Neurol. 494, 63-74.

Liu, S., Gao, X., Gao, N., Wang, X., Fang, X., Hu, H. Z., Wang, G. D., Xia, Y., and Wood, J.D. (2005). Expression of type 1 corticotropin-releasing factor receptor in the guinea pig enteric nervous system. J. Comp. Neurol. 481, 284-298.

Liu, S., Ren, W., Qu, M. H., Bishop, G. A., Wang, G. D., Wang, X. Y., Xia, Y., and Wood, J. D. (2010). Differential actions of urocortins on neurons of the myenteric division of the enteric nervous system in guinea pig distal colon. Br. J. Pharmacol. 159, 222-236.

Lovejoy, D. A. (2009). Structural evolution of urotensin-I: reflections of life before corticotropin releasing factor. Gen. Comp. Endocrinol. 164, 15-19.

Lovejoy, D. A., and Balment, R. J. (1999). Evolution and physiology of the corticotropin-releasing factor (CRF) family of neuropeptides in vertebrates. Gen. Comp. Endocrinol. 115, 1-22.

Lovejoy, D. A., and Jahan, S. (2006). Phylogeny of the corticotropinreleasing factor family of peptides in the metazoa. Gen. Comp. Endocrinol. $146,1-8$.

Lovenberg, T. W., Chalmers, D. T., Liu, C., and De Souza, E. B. (1995a). CRF2 alpha and CRF2 beta receptor mRNAs are differentially distributed between the rat central nervous system and peripheral tissues. Endocrinology 136, 4139-4142.

Lovenberg, T.W., Liaw, C.W., Grigoriadis, D. E., Clevenger, W., Chalmers, D. T., De Souza, E. B., and Oltersdorf, T. (1995b).Cloning and characterization of a functionally distinct corticotropin-releasing factor receptor subtype from rat brain. Proc. Natl. Acad. Sci. U.S.A. 92, 836-840.

Maillot, C., Million, M., Wei, J. Y., Gauthier, A., and Tache, Y. (2000). Peripheral corticotropin-releasing factor and stress-stimulated colonic motor activity involve type 1 receptor in rats. Gastroenterology 119, 1569-1579.

Mancinelli, R., Azzena, G. B., Diana, M., Forgione, A., and Fratta, W. (1998). In vitro excitatory actions of corticotropin-releasing factor on rat colonic motility. J. Auton. Pharmacol. 18, 319-324.

Martinez, V., Wang, L., Rivier, J. E., Vale, W., and Tache, Y. (2002). Differential actions of peripheral corticotropinreleasing factor (CRF), urocortin II, and urocortin III on gastric emptying and colonic transit in mice: role of CRF receptor subtypes 1 and 2. J. Pharmacol. Exp. Ther. 301, 611-617.

Mawdsley, J. E., and Rampton, D. S. (2005). Psychological stress in IBD: new insights into pathogenic and therapeutic implications. Gut 54, 1481-1491.

Million, M., Grigoriadis, D. E., Sullivan, S., Crowe, P. D., Mcroberts, J.A., Zhou, H., Saunders, P. R., Maillot, C., Mayer, E. A., and Tache, Y. (2003). A novel water-soluble selective CRF1 receptor antagonist, NBI 35965, blunts stress-induced visceral hyperalgesia and colonic motor function in rats. Brain Res. 985, 32-42.

Million, M., Wang, L., Wang, Y., Adelson, D. W., Yuan, P. Q., Maillot, C., Coutinho, S. V., Mcroberts, J. A., Bayati, A., Mattsson, H., Wu, V., Wei, J. Y., Rivier, J., Vale, W., Mayer, E. A., and Tache, Y. (2006). CRF2 receptor activation prevents colorectal distension induced visceral pain and spinal ERK1/2 phosphorylation in rats. Gut 55, 172-181.

Moss, A. C., Anton, P., Savidge, T., Newman, P., Cheifetz, A. S., Gay, J., Paraschos, S., Winter, M. W., Moyer, M. P., Karalis, K., Kokkotou, E., and Pothoulakis, C. (2007). Urocortin II mediates pro-inflammatory effects in human colonocytes via corticotropinreleasing hormone receptor 2alpha. Gut 56, 1210-1217.

Muramatsu, Y., Fukushima, K., Iino, K., Totsune, K., Takahashi, K., Suzuki, T., Hirasawa, G., Takeyama, J., Ito, M., Nose, M., Tashiro, A., Hongo, M., Oki, Y., Nagura, H., and Sasano, H. (2000). Urocortin and corticotropinreleasing factor receptor expression in the human colonic mucosa. Peptides 21, 1799-1809.

Musial, F., Hauser, W., Langhorst, J., Dobos, G., and Enck, P. (2008). Psychophysiology of visceral pain in IBS and health. J. Psychosom. Res. 64, 589-597.

Nozu, T., Martinez, V., Rivier, J., and Tache, Y. (1999). Peripheral urocortin delays gastric emptying: role of CRF receptor 2. Am. J. Physiol. 276 (4 Pt 1), G867-G874.

O'malley, D., Dinan, T. G., and Cryan, J. F. (2010a). Alterations in colonic corticotropin-releasing factor receptors in the maternally separated rat model of irritable bowel syndrome: differential effects of acute psychological and physical stressors. Peptides 31, 662-670.

O'malley, D., Julio-Pieper, M., Gibney, S. M., Gosselin, R. D., Dinan, T. G., and Cryan, J. F. (2010b). Differential stressinduced alterations of colonic corticotropin-releasing factor receptors in the Wistar Kyoto rat. Neurogastroenterol. Motil. 22, 301-311.

Okada, R., Ito, Y., Kaneko, M., Yamamoto, K., Chartrel, N., Conlon, J. M., Vaudry, H., and Kikuyama, S. (2005). Frog corticotropin-releasing hormone (CRH): isolation, molecular cloning, and biological activity. Ann. N. Y.Acad. Sci. 1040 150-155.

Okawara, Y., Morley, S. D., Burzio, L. O., Zwiers, H., Lederis, K., and Richter, D. (1988). Cloning and sequence analysis of cDNA for corticotropinreleasing factor precursor from the teleost fish Catostomus commersoni. Proc. Natl. Acad. Sci. U.S.A. 85, 8439-8443.

Palchaudhuri, M. R., Hauger, R. L., Wille, S., Fuchs, E., and Dautzenberg, F. M. (1999). Isolation and pharmacological characterization of two functional splice variants of corticotropinreleasing factor type 2 receptor from
Tupaia belangeri. J. Neuroendocrinol. 11, 419-428.

Pappas, T., Debas, H., and Tache, Y. (1985). Corticotropin-releasing factor inhibits gastric emptying in dogs. Regul. Pept. 11, 193-199.

Perrin, M., Donaldson, C., Chen, R., Blount, A., Berggren, T., Bilezikjian, L., Sawchenko, P., and Vale, W. (1995). Identification of a second corticotropin-releasing factor receptor gene and characterization of a cDNA expressed in heart. Proc. Natl. Acad. Sci. U.S.A. 92, 2969-2973.

Pisarchik, A., and Slominski, A. (2004). Molecular and functional characterization of novel CRFR1 isoforms from the skin. Eur. J. Biochem. 271, 2821-2830.

Porcher, C., Juhem, A., Peinnequin, A., Sinniger, V., and Bonaz, B. (2005). Expression and effects of metabotropic CRF1 and CRF2 receptors in rat small intestine. Am. J. Physiol. Gastrointest. Liver Physiol. 288, G1091-G1103.

Porcher, C., Peinnequin, A., Pellissier, S., Meregnani, J., Sinniger, V., Canini, F., and Bonaz, B. (2006). Endogenous expression and in vitro study of CRFrelated peptides and CRF receptors in the rat gastric antrum. Peptides 27, 1464-1475.

Qu, Z. D., Thacker, M., Castelucci, P., Bagyanszki, M., Epstein, M L., and Furness, J. B. (2008). Immunohistochemical analysis of neuron types in the mouse small intestine. Cell Tissue Res. 334, 147-161.

Rakoff-Nahoum, S., Hao, L., and Medzhitov, R. (2006). Role of tolllike receptors in spontaneous commensal-dependent colitis. Immunity 25, 319-329.

Rakoff-Nahoum, S., Paglino, J., EslamiVarzaneh, F., Edberg, S., and Medzhitov, R. (2004). Recognition of commensal microflora by toll-like receptors is required for intestinal homeostasis. Cell 118, 229-241.

Reyes, T. M., Lewis, K., Perrin, M. H., Kunitake, K. S., Vaughan, J., Arias, C. A., Hogenesch, J. B., Gulyas, J., Rivier, J., Vale, W. W., and Sawchenko, P. E. (2001). Urocortin II: a member of the corticotropin-releasing factor (CRF) neuropeptide family that is selectively bound by type 2 CRF receptors. Proc. Natl. Acad. Sci. U.S.A. 98, 2843-2848.

Rivier, J., Spiess, J., and Vale, W. (1983). Characterization of rat hypothalamic corticotropin-releasing factor. Proc Natl. Acad. Sci. U.S.A. 80, 4851-4855.

Saffran, M., and Schally, A. V. (1955). The release of corticotrophin by anterior pituitary tissue in vitro. Can. J. Biochem. Physiol. 33, 408-415.

Sand, E., Themner-Persson, A., and Ekblad, E. (2010). Corticotropin 
releasing factor-distribution in rat intestine and role in neuroprotection. Regul. Pept. 166, 68-75.

Santos, J., Saunders, P. R., Hanssen, N. P., Yang, P. C., Yates, D., Groot, J. A., and Perdue, M. H. (1999). Corticotropin-releasing hormone mimics stress-induced colonic epithelial pathophysiology in the rat. Am. J. Physiol. 277(2 Pt 1), G391-G399.

Saruta, M., Takahashi, K., Suzuki, T., Fukuda, T., Torii, A., and Sasano, H. (2005). Urocortin 3/stresscopin in human colon: possible modulators of gastrointestinal function during stressful conditions. Peptides 26, 1196-1206.

Saruta, M., Takahashi, K., Suzuki, T., Torii, A., Kawakami, M., and Sasano, H. (2004). Urocortin 1 in colonic mucosa in patients with ulcerative colitis. J. Clin. Endocrinol. Metab. 89, 5352-5361.

Saunders, P. R., Santos, J., Hanssen, N. P., Yates, D., Groot, J. A., and Perdue, M. H. (2002). Physical and psychological stress in rats enhances colonic epithelial permeability via peripheral CRH. Dig. Dis. Sci. 47, 208-215.

Seasholtz, A. F., Bourbonais, F. J., Harnden, C. E., and Camper, S. A. (1991). Nucleotide sequence and expression of the mouse corticotropin-releasing hormone gene. Mol. Cell. Neurosci. 2, 266-273.

Shibahara, S., Morimoto, Y., Furutani, Y., Notake, M., Takahashi, H., Shimizu, S., Horikawa, S., and Numa, S. (1983). Isolation and sequence analysis of the human corticotropin-releasing factor precursor gene. $E M B O$ J. 2, 775-779.

Stenzel-Poore, M. P., Heldwein, K. A., Stenzel, P., Lee, S., and Vale, W. W. (1992). Characterization of the genomic corticotropin-releasing factor (CRF) gene from Xenopus laevis: two members of the CRF family exist in amphibians. Mol. Endocrinol. 6, 1716-1724.

Teitelbaum, A. A., Gareau, M. G., Jury, J., Yang, P. C., and Perdue, M. H. (2008). Chronic peripheral administration of corticotropin-releasing factor causes colonic barrier dysfunction similar to psychological stress. Am. J. Physiol. Gastrointest. Liver Physiol. 295, G452-G459.

Thompson, R. C., Seasholtz, A. F., and Herbert, E. (1987). Rat corticotropinreleasing hormone gene: sequence and tissue-specific expression. Mol. Endocrinol. 1, 363-370.

Tsatsanis, C., Androulidaki, A., Alissafi, T., Charalampopoulos, I., Dermitzaki, E., Roger, T., Gravanis, A., and Margioris, A. N. (2006). Corticotropin-releasing factor and the urocortins induce the expression of TLR4 in macrophages via activation of the transcription factors PU.1 and AP-1. J. Immunol. 176, 1869-1877.

Tsatsanis, C., Androulidaki, A., Dermitzaki, E., Charalampopoulos, I., Spiess, J., Gravanis, A., and Margioris, A. N. (2005). Urocortin 1 and urocortin 2 induce macrophage apoptosis via CRFR2. FEBS Lett. 579, 4259-4264.

Tsatsanis, C.,Androulidaki,A., Dermitzaki, E., Gravanis, A., and Margioris, A. N. (2007). Corticotropin releasing factor receptor 1 (CRF1) and CRF2 agonists exert an anti-inflammatory effect during the early phase of inflammation suppressing LPS-induced TNF-alpha release from macrophages via induction of COX-2 and PGE2. J. Cell. Physiol. 210, 774-783.

Valdenaire, O., Giller, T., Breu, V., Gottowik, J., and Kilpatrick, G. (1997). A new functional isoform of the human CRF2 receptor for corticotropin-releasing factor. Biochim. Biophys. Acta 1352, 129-132.

Vale, W., Spiess, J., Rivier, C., and Rivier, J. (1981). Characterization of a 41-residue ovine hypothalamic peptide that stimulates secretion of corticotropin and beta-endorphin. Science 213, 1394-1397.

Van Kolen, K., Dautzenberg, F. M., Verstraeten, K., Royaux, I., De, H. R., Gutknecht, E., and Peeters, P. J. (2010). Corticotropin releasing factor-induced ERK phosphorylation in AtT20 cells occurs via a cAMPdependent mechanism requiring EPAC2. Neuropharmacology 58, 135-144. van Tol, E. A., Petrusz, P., Lund, P. K., Yamauchi, M., and Sartor, R. B. (1996). Local production of corticotropin releasing hormone is increased in experimental intestinal inflammation in rats. Gut 39, 385-392.

Vaughan, J., Donaldson, C., Bittencourt, J., Perrin, M. H., Lewis, K., Sutton, S., Chan, R., Turnbull, A. V., Lovejoy, D., and Rivier, C. (1995). Urocortin, a mammalian neuropeptide related to fish urotensin I and to corticotropin-releasing factor. Nature 378, 287-292.

Wallon, C., Yang, P.C., Keita, A. V., Ericson, A. C., McKay, D. M., Sherman, P. M., Perdue, M. H., and Soderholm, J. D. (2008). Corticotropin-releasing hormone $(\mathrm{CRH})$ regulates macromolecular permeability via mast cells in normal human colonic biopsies in vitro. Gut 57, 50-58.

Wang, L., Martinez, V., Rivier, J. E., and Tache, Y. (2001). Peripheral urocortin inhibits gastric emptying and food intake in mice: differential role of CRF receptor 2. Am. J. Physiol. Regul. Integr. Comp. Physiol. 281, R1401-R1410.

Wlk, M., Wang, C. C., Venihaki, M., Liu, J., Zhao, D., Anton, P. M., Mykoniatis, A., Pan, A., Zacks, J., Karalis, K., and Pothoulakis, C. (2002). Corticotropinreleasing hormone antagonists possess anti-inflammatory effects in the mouse ileum. Gastroenterology 123, 505-515.

Wolter, H. J. (1984). Corticotropinreleasing factor is contained within perikarya and nerve fibres of rat duodenum. Biochem. Biophys. Res. Commun. 122, 381-387.

Wu, S. V., Yuan, P. Q., Lai, J., Wong, K. Chen, M. C., Ohning, G. V., and Tache, Y. (2011). Activation of Type 1 $\mathrm{CRH}$ receptor isoforms induces serotonin release from human carcinoid BON-1N cells: an enterochromaffin cell model. Endocrinology 152, 126-137.

Wu, S. V., Yuan, P. Q., Wang, L., Peng, Y. L., Chen, C. Y., and Tache, Y. (2007). Identification and characterization of multiple corticotropin-releasing factor type 2 receptor isoforms in the rat esophagus. Endocrinology 148, 1675-1687.

Yuan, P. Q., Million, M., Wu, S. V., Rivier, J., and Tache, Y. (2007). Peripheral corticotropin releasing factor (CRF) and a novel CRF1 receptor agonist, stressin1A activate CRF1 receptor expressing cholinergic and nitrergic myenteric neurons selectively in the colon of conscious rats. Neurogastroenterol. Motil. 19, 923-936.

Yuan, P. Q., Wu, S. V., Wang, L., and Tache, Y. (2010). Corticotropin releasing factor in the rat colon: expression, localization and upregulation by endotoxin. Peptides 31, 322-331.

Zijdenbos, I. L., de Wit, N. J., van der Heijden, G. J., Rubin, G., and Quartero A. O. (2009). Psychological treatments for the management of irritable bowel syndrome. Cochrane Database Syst. Rev. CD006442.

Zmijewski, M. A., and Slominski, A. T. (2010). Emerging role of alternative splicing of CRF1 receptor in CRF signaling. Acta Biochim. Pol. 57, 1-13.

Conflict of Interest Statement: The authors declare that the research was conducted in the absence of any commercial or financial relationships that could be construed as a potential conflict of interest.

Received: 25 January 2011; accepted: 01 April 2011; published online: 20 April 2011. Citation: Buckinx $R$, Adriaensen D, Van Nassauw L and Timmermans J-P (2011) Corticotrophin-releasing factor, related peptides, and receptors in the normal and inflamed gastrointestinal tract. Front. Neurosci. 5:54. doi: 10.3389/ fnins.2011.00054

This article was submitted to Frontiers in Autonomic Neuroscience, a specialty of Frontiers in Neuroscience.

Copyright (c) 2011 Buckinx, Adriaensen, Van Nassauw and Timmermans. This is an open-access article subject to a nonexclusive license between the authors and Frontiers Media SA, which permits use, distribution and reproduction in other forums, provided the original authors and source are credited and other Frontiers conditions are complied with. 